\title{
Clocks, calendars and cell phones \\ An ethnography on time in a high school
}

\author{
Mónica Franch and Josilene Pequeno de Souza \\ Federal University of Paraíba
}

\begin{abstract}
Considering that time is an important dimension in anthropological discourse and a key element of the "hidden curriculum" of school, this paper presents the results of an ethnography on time in a high school in João Pessoa, Paraíba, Brazil. We discuss how teaching/learning processes are organized and experienced in time, paying close attention to the limitations and possibilities revealed by interactions between teachers and students. We first identify the pedagogical temporal units that compose the dimension of structural time at the school, and then identify aspects of time in practice (experiences and strategies). We argue that school time is both a constraint and an opportunity, unfolding in a series of metaphors ("save time," "waste time," "kill time", "fill time", "pass the time"), which enable ways of thinking about the conflicts present in daily school life.
\end{abstract}

Keywords: time, school, high school, youth, new information technology (NIT).

\section{Resumo}

Considerando que o tempo é uma importante dimensão para a reflexão antropológica, e um elemento fundamental no "currículo oculto" da instituição escolar, este artigo apresenta alguns resultados de uma etnografia com foco nos tempos numa escola de ensino médio em João Pessoa (Paraíba, Brasil). Nosso foco consiste em pensar o modo como os processos de ensino/ 
aprendizagem são organizados e vivenciados temporalmente, dando atenção aos limites e possibilidades que se revelam nas interações entre professores e alunos. Para isso, identificamos, em primeiro lugar, as unidades temporais pedagógicas, que compõem a dimensão do tempo estrutural da escola pesquisada para em seguida identificar aspectos do tempo na prática (experiências e estratégias). Defendemos que o tempo escolar emerge simultaneamente como constrangimento e como oportunidade, se desdobrando em uma série de metáforas ("ganhar tempo", "perder tempo", "matar o tempo", "preencher o tempo", "passar o tempo"), que permitem pensar alguns impasses presentes no cotidiano escolar.

Palavras-chave: tempo, escola, ensino médio, juventude, novas tecnologias da informação (NTI). 


\section{Clocks, calendars and cell phones \\ An ethnography on time in a high school}

Mónica Franch and Josilene Pequeno de Souza

\section{Introduction}

On a typical weekday morning between September and June some 5 million Americans kiss their loved ones goodbye, pick up their lunch pails and books, and leave to spend their day in that collection of enclosures (totaling about one million) known as elementary school classrooms. This massive exodus from home to school takes place with a minimum of fuss and bother. Few tears are shed (except perhaps by the very youngest) and few cheers are raised.

\section{(Jackson 1990:3)}

For children and adolescents, school is an important marker of daily time and an element to consider in projections about the future. The act of attending school divides the annual cycle into two periods-the school year and vacation time-, marks a distinction in the week-school days and weekends - , and even divides the day into distinct periods with respective spaces and activities. Along with family, school comes to play an important role in an individual's biography, marking the first phases of the life cycle and populating, for better or worse, an individual's memories into adult life and old age. It is in school that children and adolescents learn to fit and conform their tasks to previously established schedules, dates and places, becoming accustomed to basic elements of a discipline that, not by chance, has many similarities with the working world. In effect, school schedules, calendars, bells and clocks form part of a temporal pedagogy that reflects 
values and practices beyond the school walls, and constitute a fundamental element of the socialization promoted there. School is also a setting where other temporalities can be constructed, often in the gaps between institutional temporalities, made possible by the crisscrossing paths and practice of a wide range of sociabilities.

In an attempt to thoroughly examine the temporal dimension of school life, in this paper, we describe some reflections constructed on the basis of an ethnography of time spent in a public high school in the city of João Pessoa, capital of the state of Paraíba, in Northeast Brazil. The fieldwork ${ }^{\mathbf{1}}$ was conducted during the 2013 school year and sought to identify daily routines from the point of view of the main actors: students and teachers. ${ }^{2}$ Systematic observations were made within the premises of the school attempting to examine, to the extent possible, the full range of educational and social activities. Observations were complemented with analysis of documents and 18 semi-structured interviews (nine with students, eight with teachers, and one with the school's principal).

Our proposal in this paper is to show that not only does time represent an important regulatory dimension in academic activities, but it also constitutes the context in which teaching/learning and sociability practices and interactions are developed. We start by making a distinction between structural time (understood here as the programmatic framework of educational activities) and time lived, which includes concrete experiences (practices and significance) of time in the academic space. The distinction is analytical, since in practice both dimensions are found to be overlapping, but it becomes relevant to ask questions, such as: what are the daily conflicts experienced in the academic institution regarding time management? In what way do the subjects, with their different perspectives/positions in the school, give meaning to the time they devote to the institution? And, finally, what strategies do some use to deal with the ambiguities and pressures of school time? Our focus is to explore and reflect on the way in which teaching/learning processes are temporally organized and experienced, paying

\footnotetext{
1 Resulted in a Master's thesis defended in the PPGA/UFPB (Souza 2014). We are grateful for the contributions of the examining board, composed of Márcia Longhi and Regina Medeiros, as well as comments from Ivan Bastos in the qualification board.

2 Other authors who also are part of daily school life are the staff and the students' families, and while the latter are not present daily, they are equally important.
} 
attention to the limitations and possibilities revealed in student/teacher interactions. We argue that school time emerges simultaneously as a constraint and an opportunity, unfolding in a series of metaphors ("save time," "waste time," "pass the time"), all of which will be duly discussed below (Ramos Torre 2009).

Thus, the paper seeks to provide a contribution to anthropological studies on education from a specific perspective: understanding the school as a place where temporalities are produced, transmitted, learned and experienced. We believe this is a rare approach in an attempt to approximate school life, which could reveal implicit dynamics and frame some of the school's dilemmas from a different angle.

\section{Problematizing school time}

As occurs with space, time is a category that has mobilized anthropological thinking from the inception of the discipline (see Munn 1992; Gell 1992). The way in which societies perceive the flow of things and humans, the way in which societies organize this flow, based on establishing temporal frames of reference, the way in which activities are synchronized, the periodization and seasonality of social life-all these aspects are of interest to anthropologists; however, not always with a singular focus on one aspect separate from the others or with the depth in inquiry required. Time appears to be difficult to examine as a subject of research, as even today the Augustinian maxim echoes strongly: "The problem of time in anthropology, as in other disciplines, is subject to the Augustinian lament: how difficult to find a meta-language to conceptualize something so ordinary and apparently transparent in everyday life" (Munn 1992:116).

With respect to school, something similar happens: its times are generally not problematized; they are taken as given, and are not viewed as an integral part of the educational process unfolding therein. Our proposal here is to present the school as a place where students (children and adolescents) undergo a certain type of temporal socialization and where they also imprint new temporalities through its practices. We will present the school in the general framework of its temporal organization and then discuss specific aspects. 
According to Sue (1993), although all social practices produce their time, it is possible to establish a hierarchy that identifies some as particularly significant in a society's representation of itself. The author reserves the expression "social times" only for such times, which are responsible for the large collective rhythms, as well as for alterations that affect the rhythm of social life on a daily basis. In our society, these are the three major spheres of time: work time, free time and school time, which are all part of the ordering of the life cycle - education corresponds to childhood, work to adult life, and free time (here equal to retirement) characterizes old age. Outside of this, social times "are at the heart of the dynamic producer of social values (work ethic, learning ethic, hedonism and well-being)" (Sue 1993:64).

Within the three spheres mentioned, Sue (1993) identifies work time as being dominant in modern societies. Since school is a modern institution, the affinity between school time and work time is, in a certain sense, a given. Thus, on the edge of what is considered to be formal education explicitly taught within the school (the curricular contents of mathematics, sciences, Portuguese language, etc.), learning about a specific form of temporal perception and organization is part of the academic institution's "hidden curriculum" (Adam 1995:60), preparing students for their subsequent insertion into the world of work. "If school is the privileged place for the acquisition of disciplines and discipline, the discipline of all these disciplines is the translation of the conception, organization and management of time" (Sue 1993:66).

The elective affinity between school time and work time, more specifically the type of work that began in the Industrial Revolution, is propitiated in the first place by familiarizing the student with time measurement tools: the clock and calendar. As so aptly observed by Adam (1995:61): "Learning, teaching and even the payment of teachers are established and calculated on the basis of calendars and clocks." According to Lasén (2000:66), school functions as a "metronomic society": a society of measurements.

The use of calendars and clocks to determine the duration of social activities, as shown by Thompson (1967), is rooted in the temporal organization of monasteries, mainly Benedictine monasteries, where the monks' daily life was fractionated and determined to the most minimum detail 
(prayer time, eating time, work time, etc.). In industrial societies, the calendar/clock system became hegemonic, initially at the hands of the owners of the means of production, then closely followed by its arrival on the mantelpiece in the home, and finally, with the popularization of wristwatches, even strapped to the very body of the workers. The transition of a society to one in which time was marked by tasks done for another in the framework of abstract clock time took place at the same time the Puritan work ethic was steadily spreading, which led to changes in the perception of time. By internalizing new temporal disciplines, employers and later employees developed an economic perception of time, condensed in the famous phrase penned by Benjamin Franklin, time is money. In capitalist society, according to Thompson (1967:90-91), "all time must be consumed, marketed, put to use; it is offensive for the labour force merely to "pass the time"." Obviously, this change did not come about without some resistance, nor did it totally eliminate other temporalities, which remain, however, subordinated to clock time.

Therefore, more than constituting mere tools or technologies, the clock and school calendar reinforce in the students a certain notation of time, as well as translating values and expectations regarding the use of time, based on principles such as productivity, rationalization and efficiency: "Every task has its own optimal time. 'Time-wasting' is considered acceptable only during specially created periods of time-official break times, weekends and holidays - where it has been redefined for children and adults respectively as play-time and relaxation." (Adam 1995:64). This is because school is one of the first social spaces where disciplinary techniques are put into operation, products of a new economy of time with respect to learning, and that which Foucault calls "the docile body": "Time penetrates the body and with it all the meticulous controls of power" (Foucault 1977:152). By organizing a positive economy of time, the academic institution, in theory, aims to prevent temporal waste, optimizing the use of the students' and teachers' time; that is, extracting from their time the maximum of available moments and useful work.

If the school's temporal organization reflects a certain model of work and type of society (preparing students to adapt to the hegemonic time of industrial societies), it is to be expected that the changes affecting these societies also bring changes or conflicts in school time. In this sense, Sue 
(1993) argues that the school model described above is outdated, since the distinction between instruction (informal and less important) and education (formal and more valued) no longer has any meaning. The author believes that work time has been displaced from its dominant position in favor of free time, which is beginning to have a growing educational potential, principally due to the proliferation of the so-called new information technologies (NIT). Appropriated by the new generation (those young people that the educational academic process targets), NIT remove the monopoly of the educational act from the school and consequently multiply the actors involved in the pedagogical relationship.

Without opening a discussion here on the shifting work time/free time ratio, we would like to underscore the impact new information technologies have on the learning processes - both inside and outside the classroom. Although this trend is increasingly drawing the attention of education researchers, time as an isolated factor is not necessarily the focus of these studies (see Dwyer et al. 2007; Mamede-Neves \& Duarte 2008; Porto 2006). Among other revelations in these studies, there is an apparent consensus on the difficulty of introducing new technologies into daily school life, among other reasons because the school's very foundation is based on the figure of teacher as mediator of the student's relationship to learning, and new technologies discard the role of this mediation. In terms of the relationship to time, new information technologies free learning from its dependence on a previously established chronologically linear project that determines the contents for each phase of learning (academic curriculum) in favor of searches motivated by contingent necessity and choices. Thus, the metaphor of the net replaces the metaphor of the line as representing the learning process.

In addition to these changes and their impact on school time, it is important to note that the socialization of time as proposed by the school never occurs peacefully and without resistance. In his famous ethnography on the anti-academic culture of youth from the British working classes, Willis observes that the official notion of time in school, which values time as investment in the future, the youth counterpoint with "a sense of urgency": "time is something they want to claim for themselves now as an aspect of their immediate identity and self-direction" (Willis 1977:29). It is therefore important that we observe the way in which the various different 
actors in the school appropriate for themselves and propose other temporalities for this space.

Up to this point, we have shown that school time is a precursor to work time, providing an assimilation and training for the discipline that children and youth will later face in adult life. We emphasize, equally, that this is an implicit aspect of school, since the explicit objectives of this institution generally include the transmission of knowledge and civic formation, among other factors. Finally, we point out how changes in the work world can also lead to modifications in the way school organizes its time, or even its conflicts. Our research in this paper rests on how this temporal socialization occurs in daily life in schools attended by Brazilian youth, namely public schools, where students from the poorest population levels are enrolled.

In previous studies (Franch 2008), we suggested that public school can often present a "paradoxical socialization of time," marked by a discursive reinforcement of the values of meritocracy, based on personal effort and upholding the pillar of access to formal education, but contrasted by the daily onslaught of the routine devaluation of student's time, as observed in the constant cancellation of classes due to the shortage of contracted teachers, absences and renovations done during school time, among others. In this paper, we seek a deeper understanding of the apparent gap between discourse and practice.

\section{Research in a public high school: context and questions}

João Pessoa, with an estimated population of 780,738 , is often referred to as a peaceful city that offers a good quality of life to its inhabitants, with a range of services available but without the excessive disturbances that commonly occur in urban life. Reasonably well forested and with an attractive climate, the city is framed by well-kept urban beaches where people can go and exercise or take family picnics morning, noon or night. This image of a peaceful city, sold endlessly by the local press and national tourist agencies (and which, to a certain degree, corresponds to the lifestyles of the elite and tourists who frequent the beachside hotels), hides other less-benevolent sides of the city. As one moves beyond the surrounding suburbs, where the more well off families are concentrated, 
the city becomes diversified into neighborhoods of unequal infrastructure with reduced availability of goods and services. In one of its most unfavorable aspects, João Pessoa is notorious as the second most violent capital for youth in Brazil, with an adolescent homicide rate of 177.8 per 100,000 (Waiselfisz 2014).

The school where the study was conducted (Josué de Castro), ${ }^{3}$ is one of the largest high schools in the state of João Pessoa. It offers two shifts of high school, afternoon and evening, and its 968 enrolled students are spread out across 25 classes, with an average of 45 students per class. The school is located in Bairro do Carmo in the western part of the city, an area that was socially and economically well off but began to decline in the 1970s, as the wealthier families moved out to suburban neighborhoods, abandoning the central area. Presently, Bairro do Carmo is one of the most densely populated neighborhoods in João Pessoa, with 25,994 inhabitants, 19,388 of who are considered to be at highly at-risk socially. Most students live near the school, but others travel from other neighborhoods on public transportation to get there. This diversity is responsible for certain heterogeneity in terms of social origin, which is also reflected in the diverse appearance of the adolescents in their varying styles of dress and lifestyles.

A researcher who enters Josue de Castro High School for the first time encounters a structure that is extremely common in regional public education establishments: single-story buildings arranged around a central patio, the entire complex surrounded by a wall that separates the school complex, which occupies an entire block, from the street. All the classrooms are equipped with data projectors and air-conditioning, and the installations do not show the air of neglect often found in these spaces. The researcher then will discover, however, that it is not just any school. In 2011, a public university was installed on the premises, which brought some benefits for the operation of the school itself, especially in terms of teachers' salaries and improvement of some infrastructure items. As a counterpart, the school lost the afternoon shift and at the time of our study, some spaces were closed off and not in use. The presence of the university on the school's premises was helping improve the school's image in the city, attracting new students. Students commonly refer to the school as "the university." 
To study time in a school, the choice of a high school presents some particular features, the first of which is the generational perspective. In accordance with Article 35 of the $\mathrm{LDB}^{4}$, high school constitutes the final step in Basic Education and targets adolescents aged 15-17 years old. It is known that education in Brazil still endures a significant grade/age distortion. Although the net rate of 15-17-year-olds still enrolled in school is reportedly $84.3 \%$, only $55.2 \%$ of this group 5 effectively attends classes. Despite this distortion, high school education is symbolically and numerically assimilated to adolescence and youth, particularly with respect to daytime shifts (our study was conducted during the afternoon shift), where the grade/age ratio is more balanced. Without trying to reinforce age stereotypes, focusing on adolescents instead of children involves observing subjects with a greater degree of agency, which can be translated into challenges for the use and control of school time, motivated by the search for sociability and other generational interests. Adolescents also present more active appropriation of new information technologies, particularly cell phones and smart phones, which has emerged as a problem that schools increasingly need to address (Mamade-Neves \& Duarte 2008; Porto 2006).

Another aspect related to choice of a high school is its implicit social profile. More than 29,000 students are enrolled in the city's 94 high schools ( 46 private and 48 public). Although access to high school in João Pessoa has increased significantly, similar to what is happening in other Brazilian municipalities, the students enrolled at this level still constitute a relatively small portion of the population: $44.4 \%$ of the 15 -17-year-olds, ${ }^{6}$ who remain unevenly distributed according to their family income. National data show that only $9.8 \%$ of the 18 -24-year-olds in the richest quintile do not complete high school, while this percentage rises to 50.9\%

\footnotetext{
4 The National Education Guidelines and Framework Law, approved by the national congress in 1996, establishes the country's basic education guidelines.

5 Data from 2011, according to the document Sintese de Indicadores do IBGE [Synthesis of Social Indicators, IBGE] (2014).

6 According to the Atlas do Desenvolvimento Humano no Brasil 2013 [Atlas of Human Development in Brazil], the number of youth aged 18-20 years old who finished high school in João Pessoa rose from $17.5 \%$ in 1991 to $47.8 \%$ in 2010 . Of the $44.4 \%$ of adolescents aged $15-17$ years old in high school, $32.7 \%$ do not present any grade/ age distortion, $8.7 \%$ are behind one year and $2.9 \%$ are two years or more behind. Of the remaining $55.6 \%, 14.7 \%$ are not attending school, $27.1 \%$ are still in elementary school, $2.8 \%$ already attend university, and $10.9 \%$ are in the category "other."
} 
in the poorest quintile (IBGE 2014). In this paper, by focusing on a state high school in João Pessoa, we choose to give visibility to the experiences of youth who mainly live in working class or lower-middle class neighborhoods in the city, but whose educational history is successful in comparison with other adolescents from their same neighborhoods.

The third aspect to consider is the very purpose of high school education, which refers to the representations of the future that the school manages. Existing legislation, namely the 1996 National Education Guidelines and Framework Law (LDB in Portuguese) and the National Education Council Guidelines, attributes a broad educational objective to high school education that incorporates education for work and citizenship, ethical instruction and the development of students' intellectual autonomy and critical thinking, as well as learning several scientific and technological subjects. However, until the 1960 and 1970s, this level of education was preferentially oriented toward the preparation of an economic and/or socially select clientele for their enrollment in university. In a short time, high school education shifted to a public focus, opening to students of diverse social origins, who brought to the school, above all to public school, different backgrounds and distinct expectations (see Menezes 2001; Krawczyck 2011; Sousa \& Portela 2008). Despite the changes underway, studies indicate that schools continue reproducing bureaucratic modes of teaching, presenting the students with content that they will supposedly come to grasp and make sense of later when they are exposed to university courses, which, without this solution of continuity, becomes devoid of meaning and out of context (Menezes 2001:205).

These characteristics, which make up the current general picture of the "problems" or challenges of high school education in Brazil, present an important background when attempting to understand how time is organized in Josue de Castro, the object of our observation.

\section{On the track of structural time: units of time in Josué de Castro}

For example, try to represent what the notion of time would be without the processes by which we divide it, measure it, or express it with objective signs, a time which is not a succession of years, months, weeks, days, and 
hours! This is something unthinkable. We cannot conceive of time, except on condition of distinguishing its different moments.

\section{(Durkheim 1912:10).}

To begin our ethnographic approximation, we resolved to closely follow Durkheim's understanding (1912), investigating how the daily flow of life in the school is divided, measured and expressed. To achieve this, we identified the basic units of school time, that is, the units in the school calendar that govern the temporal logic of school practices. These units are programmed from the beginning of activities, with the aim of organizing the transfer of content and day-to-day life in the school. These are not flexible units, since they arise from a structural dimension of time, that of time planned prior to and defining of activities. In this sense, although the school has a certain degree of autonomy in relation to the arrangement of activities, it is very limited, since the planned activities must comply with the national curriculum guidelines.

The temporal units observed include:

a) The school year. This is the basic unit of school time; that is, the period in which school activities are carried out. In the case of Brazil, the school year generally runs from February to December, with vacation time in July and recess in January, dividing the year into two periods. The school year has an intrinsic relation with the academic curriculum, constituting the interval of time in which specific content must be transferred, learned and evaluated, so that students can "pass the year." Thus, knowledge is viewed as a process that occurs in a linear and cumulative way, such that the school year is supportive of the image of irreversible time. When a student is unable to assimilate all the content, it is said that he/she "lost the year," and has to repeat it again. Repeating, along with dropping out, used to be much more common situations in the past, but they are still significant in the reality of the Josué de Castro High School: in 2010 the repeat rate at the school was $19.00 \%$ and the dropout rate was $33.78 \% .^{7}$ The students who repeat need to take the same courses again with the same content, in the hope that during the second opportunity the content will be assimilated.

7 For further discussion on the culture of repetition, see Sá Earp (2009). 
Although the school year prioritizes the linear, abstract and quantitative dimensions of time, the study revealed a temporality submitted to rhythms and variations that do not depend only on the measurement of months, incorporating aspects of a qualitative order, similar to that observed in other studies (Carvalho 1993). The beginning of the year is marked by a sensation of novelty. In the classrooms, content is presented in a vivid way, students are more interested in the classes, classrooms are fuller. As the year progresses, both teachers and students appear to lose interest, especially after holidays and more markedly after the National High School Exam (ENEM) in November, which can be considered a "strong time" for students and teachers, signaling the decline of pedagogical effort for some others. ${ }^{8}$ The end of the year is a period dominated by exhaustion and by pressure: teachers need to "speed up" to be able to complete the program, students rush so as "to not be left behind." Complaints concerning the impossibility of completing the content planned for the year are unanimous among the teachers, one that by all indications is repeated year after year. In summary, although the year is presented as a homogenous unit, it feels different as the months pass: Teacher W. also complains of exhaustion and the final rush at the end of the year, in order to leave grades and exercise books up to date. Teacher E. said that students don't want to go to class and teachers don't want to give classes and that everyone is tired and they finally reach a consensus in terms of classes.

(Field note, November $19^{\text {th }}, 2013$ )

b) The bimonthly period. This is another important temporal unit, since it guides the evaluations. Every two months the school has an exam period, a time when students are evaluated with tests that attempt to measure what they have learned in the previous two months. Although the evaluations constitute "special times", since different temporalities from the routine

8 The ENEM is a test of knowledge test that is given annually in Brazil to individuals who have finished high school and to those who are over 18 years old and have not completed high school and want to obtain the degree. The exam serves as a prerequisite for entrance into a university. Although we will not examine this issue here, we mention that the ENEM appears to be an important marker in terms of teaching practices and the very objective of academic education, which can be assessed by an external institution outside the school. Teachers and students evaluate their performance based on the ENEM, whether by grades obtained (students) or by the frequency with which topics taught in class appear in the exam (teachers). The very purpose of high school is put into question in cases in which the student passes the ENEM while still in the second year, and thus comes to perceive the school year remaining as a "waste of time." For further reflections, see Souza (2014). 
week are established (students can leave early, there are no classes, etc.), they are still an integral part of the school year. Indeed, it is these exam periods that give a sense of meaning to daily school life, establishing sequences of learning, in order to optimize teaching. The interval of two months (from one exam period to another) appears to be an ideal time for learning - the period is not too long to get exhausted, and the content learned does not slip too far back in time to the point of being forgotten. As such, exam periods provide a break in the temporal continuum that are vaguely similar to the partitions presented by Hubert and Mauss (1909) in sacred time: time must be partitioned for it to become significant. In school, these intervals appear secularized and are applied in the service of controlling the progress of each student. In addition, the bimonthly exam period is complemented by several other forms of ranking that teachers use in an attempt to increase chances that students pass the year.

c) The week. It is during the week that both students and teachers experience their routine, since this is the unit of time that best translates the experience of repetition and the idea of routine. For a pedagogical perspective, the school week is understood to be the five-day period from Monday to Friday, followed by the weekend, which is the cadence in this routine. The importance of the week in the organization of school activities is evident in the fact that it is the only temporal unit with a graphic representation: the school calendar or schedule, which the students should copy in their notebook on the first day of class and then follow for their weekly activities.

d) The day. The school day is harnessed to a certain space, the school, which is separated from the street by walls and railings. For the administrative personnel and some teachers, it constitutes two shifts: afternoon and evening. For the remaining teachers and students, it includes only one shift, which lasts a little over six hours. Various factors can alter the length of a day, the most common being the absence of teachers and the resulting reshuffling of classes ("subida de aulas"), enabling students to leave early. Classes were also suspended due to unexpected events, such as lack of water or electricity, which unfortunately are not uncommon in João Pessoa.

Days differ from each other according to the schedule of materials taught and also by their position in the week. On Monday the week is "new" and everyone more rested, while by Friday, teachers and students 
have grown tired and are anxious for the weekend. Outside of this cycle, the school distinguishes certain days, following the calendar of generally recognized commemorations (including International Women's Day and Mothers' Day). Often on these occasions, the school invites students' families to a gathering at the school, opening up to the surrounding community. There are other ways, however, that the dynamics of the street can spill over into the school enclosure, marking certain days as atypical:

Arriving at school, I noted that the mood was strange, few students, almost empty classrooms but it was a normally scheduled day. In the hallway I found the superintendent and we conversed for a bit. He told me that the school was like that because of what had happened the day before [...] According to him, two criminals were being chased and after they exchanged gunfire with the police in the street, they suddenly jumped the walls of the school [...] Students were running in every direction in the hallways, while the police shot at the criminals. It was desperate and agonizing chaos. Because of this, many students were not in school today; each class had an average of seven students and other classes were not even held.

(Field note, March 27 ${ }^{\text {th }}, 2013$ )

During the study period, this was the only incident of this type, but in previous years, other tragic incidents had interrupted daily school life. The murder of a teacher and of a student, both by ex-boyfriends, mobilized the school revealing the fragility of the walls separating the school enclosure from the more general dynamics of society.

f) The class. The class is the smallest pedagogical unit of time, lasting 45 minutes, and it is one of the richest for research. The class is a moment in which students and teachers, following principles of segmentation, turn to the contents that should be given in a specific, chronometered period. The organization of school hours requires that students be willing to shift their focus of interest in each class (sometimes every two classes) and that teachers have the skills to help the students successfully make this shift and follow the specific contents presented in each class.

Classes take place in closed spaces and almost always replicate an identical arrangement of bodies and furniture; students sit at their individual 
desks, theoretically positioned to observe the teacher, though generally grouped by affinity. This spatial arrangement reflects a hierarchy regarding the control of time: in the classroom, the teacher is the master of time, but this dynamic depends on students' support for the pedagogical project developed therein. Observing daily life in classrooms, we perceived that clock time is only one of multiple dimensions at play, the scene that frames the interactions between teachers and students, riddled with negotiations that make such frameworks more flexible.

g) Recess. As its very name implies, recess is perceived as an interstice, free time, a needed escape in the school day. As such, it is not a proper pedagogical unit, since there is no content coupled to it ${ }^{9}$. Lasting only 15 minutes, though occasionally longer if the class before it ended early, recess is marked by the separation of the two main groups of actors in the school's daily life: teachers and students.

It is during recess that students can move about more spontaneously and the diversity comes into focus. One group is the evangelical students, who tend to form small cliques at recess. At events and commemorations, these students also present themselves in a different manner, singing, praising and giving testimony. Despite the monotony of the school uniform, the youths' likes and styles are apparent in colorful accessories, jewelry in the case of girls, brightly colored caps and tennis shoes for the boys, which also reflect the different patterns of consumption among them. There is evident use of cell phones and smartphones to take photos, send messages and, mostly, to listen to music in these periods, and in the classroom, denoting a generational culture marked by the compulsion to connect, to not miss anything (Agger 2011).

The above-described units show that the school day is structurally composed of four different connected dimensions. The first is the linear dimension, as attested by the school year based on the idea that the successful gaining of knowledge is a gradual and cumulative process. The second is the seasonal dimension, also reflected in the school year and to a lesser degree, throughout the day, based on the programming of intervals that establish a before and after in the principal unit of time - interval or

9 Although it may appear obvious, this is an important distinction, since in other contexts the interval is effectively incorporated into the formation, and thus considered a pedagogical unit. See Madsen (2008:168), especially in reference to schools in Hanoi (Vietnam) that use recess to perform synchronized physical activities. 
recess for the day, and holidays for the year -, roughly synchronized with periods of work time (two vacation periods during the school year, and one period from work). The third is a routine cyclical recursive dimension that appears in the day, the week, over the long term and in the year. And, finally, a segmented dimension, present in the bimonthly periods and in classes, which relates temporal clock/calendar-measured fragments with the involvement of specific activities (classes) or assessment of knowledge supposedly acquired up to a specific point in time (exams).

These dimensions, which correspond to regular times, are interspersed with special times, mainly through extracurricular activities such as contests or knowledge fairs, which provide other temporalities/spatialities in relation to regular class time, as well as other teacher-student interactions. ${ }^{10}$

\section{Meanwhile, in a classroom: dimensions lived in school time}

From time as structure that delimits and makes possible pedagogical practices, we shift our focus here to the dimensions of experience lived, revealing time as action and meaning. For this, we start with Munn's understanding of temporalization, which defines "time as a symbolic process continually being produced in everyday practices” (Munn 1992:116). The temporal unit of the class will serve as a privileged entry to offer into evidence temporal negotiations, tactics and strategies on the part of students and teachers in their daily interactions, drawing attention to dimensions such as control, power and resistance, as well as more subjective aspects that refer to temporal experiences and sensations.

a) Class management: planning vs. improvising. According to Jackson (1990:12), one of the teacher's responsibilities is "serving as an official timekeeper," deciding when activities should begin and end, whether to grant permission to students' requests (to go to the bathroom, get a drink of water, etc.), as well as announcing the moment in which the class is over, which tends to be assisted by "elaborate systems of bells and buzzers" (Jackson 1990:12). Management of class time provides evidence of the teacher's performance, and is intrinsically tied to questions like personal

10 It was not possible to address these times here. See Sousa (2014). 
investment, charisma and experience, but also to workload and general working conditions.

A key element in understanding the way teachers manage class time relates to the planning of activities. The educational system is based on the assumption that the teacher dedicates an equal or greater amount of time spent in the classroom to tasks like preparing and correcting tests, research and planning. On the other hand, it is evident that pedagogical practice requires a good dose of creativity and capacity to respond to concrete and unexpected situations. While planning is a strategy based on future time, the tactic of improvisation calls for the contingent development of activities in the present. Both these temporal orientations are present in the daily life of Josué de Castro High School: there are teachers who arrive with everything planned, others who plan with a wide margin for improvisation, and still others who do not plan the class and decide at the beginning of class what activities to do. This last situation becomes more common as the year progresses and time becomes more scarce.

In the working of class time, everything counts: life histories and school stories, anecdotes, news and TV programs, future school activities. As such, teachers' time resembles the bricoleur of Lévi-Strauss (1989), who constructs his work based on an eclectic set of materials. If, on the one hand, this bricolage approach reveals a pedagogical solution capable of connecting with the students in their daily life (sometimes more effectively than the bureaucratic contents of the disciplines), a lack of planning can also transform a class into simply passing the time, or even, into an empty way of "fulfilling" or "killing" class time until the teacher can leave:

Second and third periods were classes with teacher João. He spent the first class talking about hygiene and his experiences of falling in love and flirting in his youth and giving advice to students, and the students were greatly entertained. In the second class he talked about the cultural contest ${ }^{11}$ and assigned a task.

(Field note, May 22 ${ }^{\text {nd }}$, 2013)

11 An extracurricular weeklong event that consists of teams of students presenting specific content. The winning teams receive awards. 
The teacher arrived ten minutes late. And when she arrived she continued talking about the cultural contest. The room was noisy and chaotic. The teacher sat on the bureau looking at the class schedule and the students continued talking. The teacher asked a student to perform roll call while she organized her class notes [...] The students sing Justin Bieber in the classroom and the teacher asks for silence. The teacher continues to sit on the bureau, barely interacting with the students.

(Field note, May 27th, 2013)

b) Scarcity, experience and exhaustion: facets of teachers' time. The difficulty teachers face in planning their classes needs to be situated in the general context of the conditions of involvement in educational work, widely discussed in the specialized literature. In addition to being exposed to the growing intensity and precariousness of the work (Lelis 2012), teachers must often face "violence, insecurity, bureaucracy, low pay, lack of perspective of career promotion, overcrowded classrooms," as well as "long working days" and the "intense rhythms of educational work" (Alvarenga 2008:100).

In Josué de Castro High School, most teachers supplement their income through part-time work at different schools, spending a good part of their time teaching classes and correcting tests in heavy work schedules, leaving little time for planning. On some occasions, we observed them using part of the class to put their papers and class notes in order while the students performed some learning activity or conversed among themselves. The demands intensify during exam periods, when the teachers must correct the tests and record the grades of all students in the gradebook. There is no doubt that time, in this sense, acts as oppressor of teaching activities, as corroborated by similar results from several studies already conducted in Brazil on elementary and secondary school teachers (Alvarenga 2008, Carvalho 1993):

In the interval between classes, the teacher told me that he was tired, that he had already taught six classes that morning. He teaches three different subjects in another school. He told me that in the other school he uses a microphone to give classes and that sometimes he brings the microphone to this school 
as well. On average, his classes have 60 students and that after this school, he is going to another to teach the night shift as well. This is his routine on Mondays, Wednesdays and Fridays. The pace slows down a bit on Tuesdays and Thursdays, but he teaches classes every day.

(Entry in field notes, November $8^{\text {th }}$, 2013)

A scarce resource in daily life, in the long run, time can function as an asset accumulated in the form of experience. Time as an acquired resource emerges in the conversations of some teachers in a similar way to a "time bank" that offsets everyday urgency, as well as valuing age/time of service, therefore differentiating experienced teachers from novices. Without substituting the need for planning and creativity, experience condenses accumulated knowledge through years of practice of the occupation, including the ability to deal with situations that vary widely from what the teacher sees as ideal: "My day today is hectic, as I told you, but since I have experience teaching that subject and I always teach that class, all year, I already have everything in mind, due to years of experience." (Interview with a teacher; emphasis added).

If time accumulated in educational activity can be transformed to experience, valuing a life lived teaching, this same time can also transmute into exhaustion and depletion, generating divestment in the teaching career and the construction of new life projects outside teaching, after retirement: "since I'm already at the end of my career, when I complete 50, I won't wait a day longer. I've already given what I have to give to education" (interview with a teacher). Exhaustion, stress, anxiety, disappoint and illness form part of the daily life of the majority of teachers, some of whom are burdened by many years of service. When accumulated time is synonymous with depletion, younger teachers, however less experienced, have the advantage of still "having something to give" to education and their teaching efforts can engage students more:

The second class was [...] with teacher Rafael. He is new to the school, recently graduated. I admit his class surprised me [...]. Students not only paid attention, but participated in class. I was left wondering if it was because the teacher was young and spoke the same language as the students. Although the class was 
short and the teacher dismissed the students before the end of the period, I believe it was a productive class in the sense that the central idea proposed by the teacher was effectively communicated.

(Field note, March $7^{\text {th }}$, 2013)

c) Teaching resources and class time management. The most common pedagogical resources used by teachers in Josué de Castro High School are the white board, the data projector, and the textbook. The board is by far the most widely used tool, although students do not show much interest. Many students do not copy the contents in their notebooks, instead they listen to music or leave the room, they make a racket every time the teacher turns their back to write. The use of the board appears to be more efficient, in terms of adhesion, when the teacher uses it to write tasks that the student must answer during the class. Without entering into the merits of the "copying" method, the amount of time students spent copying in their notebooks was noteworthy when compared with the limited time devoted to pedagogical interaction.

The teacher asked a student [...] to write a short text on the board for the students to translate and earn bonus points. [...] Meanwhile, the students copied the activity and whispered among themselves, the class was calm in comparison with others. [...] The girl who was copying the activity did her best to stand out. When they finished copying the text, the majority of the students put away their notebooks and continued talking or listening to music on their cell phones.

(Field note, May $\left.15^{\text {th }}, 2013\right)$

In contrast, the data projector frees up the time spent copying in a notebook, enabling greater teacher-student interaction. The problem with this is the brightness of the classroom: "The teacher presents the material [...] using the projector, but it can barely be seen since the room is so bright and it is not easy to see what is on the slides," the students complain (Field note, 4 March 2013). Lastly, the textbook is the least-used resource, which causes numerous complaints among the students. 
Even regarding the importance of factors like accessibility and the crystallization of pedagogical practices (such as copying from the board), we propose understanding these technologies from the perspective of the control and economy of time. When used as support at certain moments during the class, the whiteboard can function like a breath for the teacher, a moment of pause between one interaction and the next, serving to fix knowledge and diversify the activities in the class. However, when the entire class consists of "copying text" from the board into the students' notebooks, this resource tends to function as a pastime, a way for the teacher to fill out or meet the requirements of the 45-minute class while they control the students-even though it may not be successful. However, the use of the data projector, while not as adequate from a technical viewpoint (due to problems of visibility) enables the teacher to save time, due to the possibility of reusing the content for more than one class, even year after year. Here we have two mutually defining dimensions of pedagogical time: the class appears to be an extensive period that needs to be filled, while time outside class, which serves as support for the former, is scarce and must be fully exploited.

d) Jumps in time: absent teachers vs. absent students. Another factor that stands out in relation to time in classes is the frequency of "aulas vagas," a phenomenon commonly observed in several other studies (Carvalho 1993; Franch 2008) and that is cause for complaints in online debate forums on public school issues. ${ }^{12}$ An aula vaga [lit. vacant class] is a class that, although included in the school's daily schedule, for some reason does not take place. In many schools, this occurs due to a shortage of contracted teachers, but this is not the case at Josué de Castro; the school was fully staffed at the time of our research. Our study observed that aulas vagas were the direct result of the absence of a teacher from work. An absence may be official via some formal permission (for example, medical leave); however, in the majority of cases, it has to do with being absent for one day, or departing early from school (whether in agreement with the principal's office or not), and affects the temporal organization of the school in its daily routines.

12 See Pierro (2014), in widely disseminated text on public education debate forums on the internet. 
Far from being an infrequent situation, in Josué de Castro, aulas vagas are incorporated into the school's routines, leading to a reorganization of activities called "subir aulas" ("moving classes up"). When a teacher is absent, the teacher from the last or second-to-last class of the shift is asked to take the class in place of the missing teacher. Since teachers' schedules are totally full, this request means that any teacher receiving this request is being asked to cover two classes simultaneously (usually in two classrooms). "Moving classes up" is a strategy for everyone to "save time," enabling students and teachers to end the school day early, which occurs at the expense of the content of the classes:

In this classroom there were two classes because $1 \mathrm{C}$ had a vacant class and so they decided to put the two classes together and it was difficult for the teacher to control so many students. He appeared very stern and he kept calling the students to order

(Field note, March $12^{\text {th }}, 2013$ )

While the students took the test and conversed, the teacher was talking with me about the school's policy to move classes up. He said that it had its good points and its bad points. When a teacher splits their time between two classrooms, according to him, he can do neither one thing nor the other, so for him there is no upside. He finds the running around terrible and as such, he thinks it is better to stay later rather than move the classes up and leave earlier. He said that he does not like it at all.

(Field note, October 3rd, 2013)

Another situation that occurs is students actively "skip" classes. By tracking the same classes throughout the year, we observed that the number of students attending class fluctuated significantly. The first classes of the day tended to report higher absentee rates, leading to a stricter policy on the practice of letting students arrive after the first class. The last classes also tended to have more absentees.

Often when students were absent, it meant that they did not come to school that day. Frequently, however, students would come to school and 
remain on the premises, but outside the classrooms, and then decide to skip a certain class or leave early. Skipping a class is usually not a random individual decision. It tends to involve more than one student and reveals an effort to pursue other uses, forms and rhythms of time than remaining in the classroom, as they perceived it:

I skipped purely out of mischief, I didn't care about anything, I only came to school to hang out, to talk with other students outside. That was mostly how it was, chatting outside, talking nonsense, I missed a lot classes. I couldn't care less about grades, roll call, any of it. (Eduardo, 19, first year)

Students who skip class [play hooky] are also selective and are more likely to skip classes they consider to be less important and teachers they judge to be worse. In this sense, these decisions contain an element of criticism about these classes that, for those skipping, are a "waste of time":

In fourth-period class I found Ray and Renata in the school hallway heading home; they were skipping class. I remained there talking with them [...] the superviser saw us and came over to speak to us, primarily with the kids about skipping, about them simply skipping and that they shouldn't be doing that, and that leaving class to go home wasn't right [...]. The students said they had no motivation and were disappointed with the classes in [2 subjects].

(Field note, September $13^{\text {th }}$, 2013)

e) Goofing off and gabbing: students' time. Between skipping class and actively participating in class, a series of matrices mark different attitudes of the students in relation to what takes place in the classroom. One of the biggest challenges for the teachers, individually, and the school as an institution, is getting students to support the pedagogical project being developed there. "Anyone who has ever taught cannot help having wondered from time to time whether his students were with him or not." (Jackson 1977:86). In the case of Brazil, studies show that the teachers focus their pedagogical action only on those students who closely accompany the progress of the class, reproducing a division like that of the center/ periphery, a practice that ends up contributing to the so-called "culture of repetition" by not motivating students who are having difficulty (Sá 
Earp 2009). In Josué de Castro, this type of pedagogical selection was also observed.

The students are roughly divided into two groups: one group sits closer to the front and is motivated to participate in class; the other sits at the back of the classroom, the infamous "rowdy bunch":

Some students pay attention, the teacher scolds the rest who are talking and says that those who do not want to assist the class can leave the room. At the same time, the students complain that they do not understand the subject but they also appear bored by the teacher's explanations. The teacher takes questions from some of the students, focusing on those who are more interested. The group at the back converses openly. I observe little use of cell phones, hardly any. While the teacher takes questions from some students, two students put on makeup at the back of the room.

(Field notes, May $7^{\text {th }}$, 2013)

This class is really polarized. Some girls at the back of the room seem to enjoy chaos and disruption; they keep provoking other girls in front. They all argue and swear during the class and threaten their classmates. One girl told me that they are connected with the "Okaida." ${ }_{13}$ Confusion breaks out in the room over the competition because these girls do not want to contribute money to perform the tasks for the competition, the banner and model, and they said that whoever contributes will have to face them. And they spent the whole class talking loudly to intimidate their peers, while the teacher pretended to see nothing and continued giving his lesson.

(Field note, May 2oth, 2013)

Misbehaving, messing around, disrupting the progress of the classall these are frequent behaviors that seek to pressure teachers to cut short the class. They are also ways of temporalizing (Munn 1992:116) or making

13 Okaida (OKD) and Estados Unidos (USA) are two rivaling gangs in João Pessoa that have channeled the rivalry between youths in different neighborhoods; this has affected school attendance in some of these neighborhoods. The presence of these two gangs in the local scene has been considered an important element in the growing adolescent death rate due to external causes in the city. 
time s creating moments that stand out in the monotony of the classes and that become part of the repertoire of memories of youth. As Willis (1977) observed in his ethnography on groups of working class English youths, it has to do with attitudes in the present, since these attitudes enable certain students to stand out among their peers, challenging teachers' authority and showing astuteness and humor. It should be noted, however, that unlike that observed by Willis (1977), the "tactics of resistance" here are not the monopoly of young males. Young females are also protagonists, and not only discretely but also assertively, as narrated in the second scene.

In addition to the internal divisions, there is a general understanding in the school that certain classes are more difficult than others: "A very disruptive class, notorious for being considered one of the worst in the school," "Some teachers had already indicated that this class was rowdy." The difficulty that teachers had controlling classes labeled as "rowdy" was palpable, and they commonly complained of how hard it is to exercise their authority, sometimes referring to the school of the past wistfully (Souza 2014). However, observing the same groups of students over the entire day, it was evident that they do not behave the same way in all classes, valuing some more than others. The pedagogical resources used, interest in the subject, and, above all, the interactions that the teacher is able to establish with them all appear to be fundamental in this difference of attitude.

Orderly or rowdy, all the students appear to value the school as a space not only for learning, but above all for socializing. Few dating scenes were observed, but conversation is present all the time, inside and outside the classrooms: "The class was very agitated, lots of chatting"; "The students there at the back don't stop talking"; "When they finished the activity, the teacher looked at them and they continued talking until the class was over"; "Afterward the students continued talking until recess"; "Even though they were talking, most did the activity"; "The teacher made a call while the students talked loudly among themselves." Conversation constitutes a moment of friendliness in the midst of pedagogical time, providing a positive motivation for going to school: "I am well connected, I like being around these people, from the man standing at the entrance 
to the cafeteria ladies, I talk with them all, I really like each and every one and, concerning my classmates, I can say that I have made real friends" (Iracema, 15, first year).

g) Escaping from "jail": cell phones and smart phones. All the students in Josué de Castro have cell phones; many even have smartphones and spend a good deal of their time on the internet, mostly gaming or browsing social networks, such as Instagram and Facebook. Some also use class time to listen to music on their headphones and send messages to their classmates. So, in some sense, these young people are always writing or sending messages or informing themselves, only they do not do it in the way that the school determines: "Writing teachers lament the decline of discourse, but kids write furiously, even if their terms papers on Shakespeare are uninspired" (Agger 2011:128).

The cell phone is a faithful companion at all times in all classes, a generational mark that makes its presence in the entire school. A parallel time has come to exist, a "second class" that occurs simultaneously with the traditional teacher-led class. Use of a smartphone does not necessarily imply that the student is unaware of what is taking place in the classroom, since they have learned to pay attention to several activities at the same time (multitasking), with fluctuating attention. On many occasions, however, the use of technology functions as an escape, enabling students to meet the obligation of remaining in the classroom, without fully sharing in the pedagogical space: "Schools are prisons, and phones allow the inmates to stay connected by tapping on the walls of their own cells" (Agger 2011:128).

Some teachers, recognizing and understanding the students' fascination with new technologies, view cell phones and smartphones as providing potential teachable opportunities: "Virtually all students have cell phones that are connected to the internet all the time, they research everything on their phones, so I present the activity and say: research that on your cell phone [...] While I observed they were all researching" (interview with a teacher). The majority, however, consider that these "digital natives" are wasting the opportunity they have on superficial irrelevant information: "The kids have easy access, they know how navigate it better than we do, they have all the knowledge, but unfortunately I think correct adequation is still lacking because they use it much more to pass 
massages, play games, listen to music, than for didactic purposes, as a pedagogical resource" (interview with a teacher). For some teachers, especially those close to retiring, cell phones and smartphones emerge as symbols of their being out of sync with the students' world, and they voice other complaints about the profound changes in high school education in recent decades:

[The teacher] told me how disillusioned she was with the profession, that she does not feel valued and respected like she used to, that she has almost 30 years of experience in the classroom and today she is embarrassed to say she is a teacher because today's students do not respect teachers. [She also told me] that new technologies only disrupt things, that she is an old-fashioned teacher, traditional, who likes to use books and she feels nostalgia for the past, when the student respected the teacher. [...] She asked me if I sincerely thought that new technologies helped because she herself thinks they do not, because before students researched in a book and now they don't even read, they only copy and paste from the computer, she doesn't see any improvements and she doesn't even have hope.

(Field note, October $2^{\text {nd }}$, 2013)

\section{Final considerations}

In this paper, we propose a reading of daily life in school based on a classic category in anthropology studies, though one that is usually secondary in analyses of Brazilian schools: time. Following the inspiration of Durkheim (1996), we began identifying the school's temporal units, understood here as structural time, that operate as a framework for the principal activities that organize daily life and a student's progression through the school system. Next, we contrast these units with the lived dimension of time, that is, with time constructed by the practices of the subjects (Munn 1992), focusing in particular on the negotiations and experiences in the classroom setting. If by thinking in structural time we are dealing with expressions such as "class time," "school year" and "schedule," then time lived brings us to temporal sensations that pose 
questions of social rhythms, the limitations of the body, expectations in relation to what each moment in time brings to the individuals, thus translating the fabric of life_-"exhaustion," "laziness," "indifference," "anxiety," "waiting," "excitement."

Thus, school time emerges simultaneously as a constraint and as an opportunity; not just an external, imposed time, but a time equally constructed by the subjects that populate this space, in their mutual relationships. From the teachers' point of view, we observe that some practices that appear not to make sense in terms of efficiency, and that we can understand based on the metaphor of "filling time," should be contextualized within the current conditions of educational work, which generate a precarization of teaching in its material and symbolic aspects (Lelis 2012). This understanding is particularly pertinent in the school studied, since many teachers find themselves nearing the end of their career, in a phase of clear divestment (Lemos 2009). Even among those who are engaged in their work, it is rare to find a teacher who does not show any type of time constraint, although time can also be a positive resource, specifically when it translates into experience. In this sense, teachers' time appears as a scarce resource when we think of their working day, a vacuum to be filled (the 45 minutes of class time), and as an embodied trajectory in a positive way (experience) or negative way (exhaustion, depletion).

From the students' point of view, "saving time" appears to be one of the most significant metaphors (Ramos Torre 2009), whether over the long term, when questioning the importance of school after the ENEM (Souza 2014), or in the daily routine, as observed in the ordinary negotiations of leaving class early. On these occasions, students rely on the "power of the weak," making it unfeasible to continue the class ("goofing off") or even to hold it ("mass skipping"). They also create other times in the classroom, imprinting on the school their own uses, usually tied to socializing with their classmates, which has little to do with the school's formal objectives, and at times even contradicts them. In this sense, despite having less power in the school structure, they experience time more as an opportunity than as a constraint; this opportunity, however, is frequently anchored in the present, without necessarily pointing toward the future. 
The frequent (structural and generational) mismatch between teachers' time and students' time invites us to think of Mannheim's theses on the "noncontemporariness of those who are contemporary": both are in the same school, but the time of this school has different significations for its numerous actors. The whiteboard and smart phone are metaphors of this mismatch: the time of the board is slow, accompanying the hand that is writing, in the expectation that copying permanently imprints the learning in the exercise book and in the memory; the time of the smartphone is fast, messages connect the student with friends in the street, music allows them to participate in youth culture, social networks instantaneously inform them what is occurring outside, but also invites them to quickly forget what they have learned. While the classmate at the next desk took 15 minutes to copy what was on the board, the student took a photo and stored the information in their device. Students may be "digital natives" but they do not have "experience." Teachers have "experience," and some are even digital natives, but others view new technologies as a threat. There are many routes to roam in many different directions, in order, as one teacher said, "to reach a consensus."

Received 31 December, 2014, approved 17 June, 2015

Translator: Lyle Prescott

Revised by Philip Bain

\section{References}

AGGER, Ben. 2011. "iTime: labor and life in a smartphone era". Time \& Society, 20(1): 119-136.

ADAM, Barbara. 1995. Timewatch: the social analysis of time. Cambridge: Polity Press.

ALVARENGA, Carolina Faria. 2008. Relações de gênero e trabalho docente: jornadas e ritmos no cotidiano de professoras e professores. Dissertação de Mestrado, Programa de Pós-Graduação em Educação (Dissertação de Mestrado em Educação) - São Paulo.

CARVALHO, Marília Pinto. 1993. "Ritmos, fragmentações: tempo e trabalho docente numa escolar de 10 grau". Cad. Pesq. São Paulo, 84: 17-30. 
DURKHEIM, Emile. 1912. The Elementary Forms of the Religious Life. Mineola, NY: Dover Publications Inc.

DWYER, Tom et al. 2007. "Desvendando mitos: os computadores e o desempenho do sistema escolar”. Educação \& Sociedade, 28(101): 13031328.

FRANCH, Mónica. 2008. Tempos, contratempos e passatempos: um estudo sobre práticas e sentidos do tempo entre jovens de grupos populares do Grande Recife. Tese de Doutorado, Programa de Pós-Graduação em Sociologia e Antropologia - Rio de Janeiro.

FOUCAULT, Michel. 1977. Discipline and Punish: The Birth of the Prison. New York: Vintage Books.

GELL, Alfred. 1992. The Anthropology of Time. Oxford: Berg.

INSTITUTO BRASILEIRO DE GEOGRAFIA E ESTATÍSTICA. 2014.

Sintese de Indicadores Sociais. Uma análise das condições de vida da população brasileira 2014. Rio de Janeiro: IBGE.

JACKSON, Philip W. 1990. Life in Classrooms. New York: Teachers College Press.

JOÃO PESSOA. Topografia social de João Pessoa. João Pessoa: Prefeitura Municipal de João Pessoa, 2012. (http://www.joaopessoa.pb.gov.br| portal/wp-content/uploads/2012/o4/TOPOGRAFIA-SOCIAL-DE-JOAOPESSOA_2009.pdf)

KRAWCZYCK, Nora. 2011. "Reflexão sobre alguns desafios do Ensino Médio no Brasil hoje”. Caderno de Pesquisa, 41(744): 752-762.

LASÉN, Amparo. 200o. A contratiempo. Un estudio de las temporalidades juveniles. Madrid: Centro de Investigaciones Sociológicas.

LEMOS, José Carlos Galvão. 2009. Do encanto ao desencanto, da permanência ao abandono: o trabalho docente e a construção e a construção da identidade profissional. Tese de Doutorado, Programa de Pós-Graduação em Educação, PUC/SP - São Paulo.

LEVI-STRAUSS, Claude. 1989. O pensamento selvagem. Campinas, SP: Papirus.

LELIS, Isabel. 2012. "O trabalho docente na escola de massa: desafios e perspectivas”. Sociológicas, 14(29): 152-174.

MADSEN, Ulla Ambrosius. 2008. Toward eduscapes: youth and schooling in a global era. In: HANSEN, Karen Tranberg (Ed.). Youth and the city in the Global South. Bloomington, In: Indiana University Press:151-173. 
MAMEDE-NEVES, Maria Aparecida Campos; DUARTE, Rosalia. 2008. "O contexto dos novos recursos tecnológicos de informações e comunicação e a escola”. Educ. Soc., 2(104): 769-789.

MENEZES, Luis Carlos de. 2001. "O novo público e a nova natureza do ensino médio". Estudos Avançados, 15(42): 201-208.

MUNN, Nancy. 1992. "The cultural anthropology of time: a critical essay". Annual Review of Anthropology, 21: 93-123.

PIERRO, Giulia. 2014. “Aula vaga: você sabe o que é isto?” In: http://www2. uol.com.br/aprendiz/n_colunas/coluna_livre/id140101.htm - Accessed on: November 2014.

PORTO, Tania Maria Esperon. 2006. “As tecnologias de comunicação e informação na escola; relações possíveis... relações construídas”. Revista Brasileira de Educação, 11(31): 43-57.

PROGRAMA DAS NAÇÕES UNIDAS PARA O DESENVOLVIMENTO (PNUD). 2013. Atlas do desenvolvimento humano do Brasil. PNUD. Available at: http://www.pnud. org.br/atlas/ Accessed on: November 2014.

RAMOS TORRE, Ramón. 2009. "Metáforas del tiempo en la vida cotidiana: una aproximación sociológica”. Acta Sociológica, 49: 51-69.

SÁ EARP, Maria de Lourdes. 2009. "A cultura da repetência em escolas cariocas”. Ensaio: Aval. Pol. Públ. Educ., 17(65): 613-632.

SOUSA, Sandra Sákia; PORTELA DE OLIVEIRA, Romualdo. 2008. “Ensino médio noturno: democratização e diversidade”. Educar, 30: 53-72.

SOUZA, Josilene Pequeno. 2014. Ritmos, tempos medidos e tempos vividos: Uma etnografia do tempo escolar. Dissertação em Antropologia, Programa de Pós-Graduação em Antropologia, Universidade Federal da Paraíba - João Pessoa.

SUE, Roger. 1993. "La sociologie des temps sociaux: une voie de recherche en éducation”. Revue Française de Pédagogie, 104: 61-72.

THOMPSON, Edward P. 1967. “Time, work, and industrial capitalism". Past and Present, 38: 56-97.

WAISELFISZ, Julio Jacobo. 2014. Mapa da violência 2014. Os jovens do Brasil. Rio de Janeiro: Flacso Brasil.

WILLIS, Paul E. 1977. Learning How to Labour: How Working Class Kids Get Working Class Jobs. Farnborough: Saxon House. 
Mónica Franch

Federal University of Paraíba

monicafranchg@gmail.com

Josilene Pequeno de Souza

Federal University of Paraíba

josipequeno@hotmail.com 